Volume 10 Issue 3, July-September 2016: pp. 413-. Copyright (c) 2015-2016 FIAT JUSTISIA. Faculty of Law, Lampung University, Bandarlampung, Lampung, Indonesia. ISSN: 1978-5186 | e-ISSN: 2477-6238.

Open Access: http://jurnal.fh.unila.ac.id/index.php/fiat

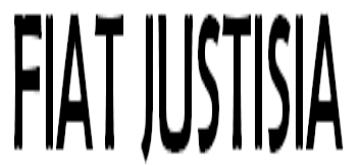

Fiat Justisia is licensed under a Creative Commons Attribution 4.0 International License, which permits unrestricted use, distribution, and reproduction in any medium, provided the original work is properly cited.

\title{
EKSEKUSI JAMINAN HAK TANGGUNGAN SEBAGAI UPAYA PENYELESAIAN PEMBIAYAAN BERMASALAH (Studi pada PT Bank Muamalat Indonesia Cabang Lampung)
}

\section{Foreclosure as An Effort to Resolve the Mortgage Payment Problems (A Study on PT Bank Muamalat Indonesia Branch Lampung)}

\author{
Marnita \\ PT.Bank Muamalat Cabang Lampung \\ email: bunga_haroki@yahoo.co.id
}

\begin{abstract}
The execution of foreclosure can only be implemented if the results of the analysis states that there is no ability and no goodwill from the customers to return the loans and it also has passed through several stages of restructuring to a set of schedule. However, the customers are still not able to meet their obligations. The procedure of foreclosure on PT Bank Muamalat was done through non-litigation stage by conducting offsetting in accordance with Article 20 (2) and (3) UUHT and through the stage of litigation (Legal Line / Courts). The execution of auction on PT Bank Muamalat Branch Lampung has been done in two ways: First, the bank applied for Write of Execution of Mortgage right to the Religious Court in accordance with Article 14 paragraph (2) UUHT. Second, the Bank can also apply for an auction execution directly (parate execution) to the State Property Office and Auction (KPKNL) in accordance with Article 6 UUHT. According to Mursalah Mashalihul theory and The theory of 'Urf, the practice of mortgage rights is in conformity with the Islamic law.
\end{abstract}

Keywords: Islamic Banking, Foreclosure, Mortgage Payment Problems

\begin{abstract}
Abstrak
Eksekusi jaminan dengan memenuhi syarat yaitu hasil analisa menyatakan bahwa tidak ada kemampuan dan niat baik nasabah dalam mengembalikan pembiayaan, telah melalui restrukturisasi. Namun dari upaya tersebut
\end{abstract}


nasabah belum juga dapat memenuhi kewajibannya. Prosedur eksekusi jaminan yaitu melalui tahapan Non Litigasi yaitu penjualan dibawah tangan (Offsetting) sesuai dengan Pasal 20 ayat (2) dan (3) UUHT dan melalui tahapan Litigasi (Jalur Hukum/Pengadilan). Praktek lelang eksekusi jaminan hak tanggungan dilakukan dengan dua cara, yaitu: Pertama, Bank mengajukan permohonan fiat eksekusi Hak Tanggungan kepada Pengadilan Agama berdasarkan Pasal 14 ayat (2) UUHT. Kedua, Bank juga dapat mengajukan permohonan lelang eksekusi terhadap objek Hak Tanggungan secara langsung (parate eksekusi) ke Kantor Pelayanan Kekayaan Negara dan Lelang (KPKNL) sesuai Pasal 6 UUHT. Melalui teori Mashalihul Mursalah dengan mengambil filosofi kemanfaatan bagi orang banyak dan Teori 'Urf sesuai dengan qaidah "Al- 'adatu muhakkamah" (Adat kebiasaan itu merupakan syari'at yang ditetapkan sebagai hukum) ditemukan bahwa Hak Tanggungan dalam penerapannya sudah sesuai dengan Hukum Islam.

Kata Kunci: Perbankan Syariah, Eksekusi Jaminan, Hak Tanggungan, Pembiayaan Bermasalah

\section{A. Pendahuluan}

Pelaksaanaan pemberian pembiayaan pada umumnya dilakukan dengan mengadakan suatu akad/perjanjian. Perjanjian tersebut terdiri dari perjanjian pokok yaitu perjanjian utang piutang dan dengan perjanjian tambahan berupa perjanjian pemberian jaminan oleh pihak debitur. Secara garis besar dikenal ada 2 (dua) bentuk jaminan, yaitu jaminan perorangan dan jaminan kebendaan. Dalam praktik jaminan yang sering digunakan adalah jaminan kebendaan yang salah satunya adalah tanah yang dijadikan jaminan atau disebut Hak Tanggungan. Pemberian jaminan dengan Hak Tanggungan diberikan melalui Akta Pemberian Hak Tanggungan (APHT) yang didahului dan atau dengan pembuatan Surat Kuasa Membebankan Hak Tanggungan (SKMHT) merupakan bagian yang terpisahkan dari perjanjian akad pembiayaan.

Perjanjian akad pembiayaan mempunyai kedudukan sebagai perjanjian pokok, artinya merupakan sesuatu yang menentukan batal atau tidak batalnya perjanjian lain yang mengikutinya. Perjanjian akad pembiayaan dengan Jaminan Hak Tanggungan bukan merupakan hak jaminan yang lahir karena Undang-Undang melainkan lahir karena harus diperjanjikan terlebih dahulu antar bank selaku kreditur dengan nasabah selaku debitur. Oleh karena itu secara yuridis pengikatan jaminan Hak Tanggungan lebih bersifat khusus jika dibandingkan dengan jaminan yang lahir berdasarkan Undang-Undang sebagaimana diatur dalam Pasal 1131 KUHPerdata. 
Sebenarnya dalam konsep jaminan hukum Islam tidak dikenal istilah Hak Tanggungan dan pada prinsipnya juga tidak ada dalam konsep perbankan syariah. Namun, selama ini yang terjadi dalam praktek Perbankan Syariah, pembiayaan yang dilakukan oleh bank syariah salah satunya juga dilekatkan suatu jaminan kebendaan secara Hukum Perdata yang berlaku di Indonesia. Hal ini untuk memudahkan penyelesaian jika terjadi wanprestasi. Jaminan yang biasa dilekatkan adalah Jaminan Hak Tanggungan. Padahal jika diamati bahwa perjanjian yang dilakukan di Perbankan Syariah adalah berdasarkan hukum Islam dan prinsip-prinsip Hukum Perjanjian Islam. Sedangkan mengenai pengikatan jaminannya dilakukan atau didasarkan pada Hukum Perdata Indonesia. Oleh sebab itu penulis menyebutnya adalah terjadi percampuran dua (2) prinsip hukum yang dilakukan oleh Perbankan Syariah. Namun harus disadari dalam proses eksekusi jaminan hutang tersebut, syariat Islam belum mengatur tentang tata cara pelaksanaannya. Sehingga diperlukan kajian terhadap proses eksekusi yang dilakukan oleh Perbankan Syariah terhadap jaminan pembiayaan bermasalahnya.

Eksekusi jaminan hak tanggungan merupakan langkah terakhir yang dilakukan kreditur selaku penerima hak tanggungan apabila debitur selaku pemberi Hak Tanggungan cidera janji (wanprestasi). Pelaksanaan eksekusi tersebut diatur dalam Undang Undang Nomor 4 Tahun 1996 tentang Hak Tanggungan Atas Tanah Serta Benda-benda Yang Berkaitan Dengan Tanah Bab V tentang Eksekusi Hak Tanggungan.

Persoalan yang muncul mengenai kewenangan menyelesaikan sengketa ekonomi syariah oleh Peradilan Agama adalah ketika Penjelasan Pasal 55 ayat (2) Undang-Undang Nomor 21 Tahun 2008 tentang Perbankan Syariah memberikan kompetensi atau kewenangan kepada Pengadilan dalam lingkungan peradilan umum untuk menyelesaikan sengketa perbankan syariah sehingga menimbulkan ketidak pastian hukum. Ada anggapan bahwa adanya choice of forum (pilihan tempat penyelesaian sengketa) dalam penjelasan pasal tersebut karena hakim Pengadilan Agama belum familiar dalam menyelesaikan sengketa ekonomi syariah. Hal ini sangat berpengaruh terhadap kompetensi Pengadilan Agama khususnya terhadap penyelesaian sengketa Perbankan Syariah, terlihat pada klausul akad-akad di Perbankan Syariah yang masih mencantumkan redaksi penyelesaian sengketa melalui jalur litigasi dalam hal ini pengadilan dalam lingkup pengadilan umum.

Dari uraian latar belakang di atas penulis tertarik untuk mengaji beberapa permasalahan yang terdiri dari; 1) Bagaimana syarat dan prosedur eksekusi jaminan yang dilakukan oleh PT Bank Muamalat Indonesia Cabang Lampung dalam upaya penyelesaian pembiayaan bermasalah?; 2) Bagaimana praktik pelaksanaan lelang eksekusi jaminan hak tanggungan yang dilakukan oleh PT Bank Muamalat Indonesia Cabang Lampung?; 3) Apakah eksekusi jaminan hak tanggungan yang dilakukan oleh PT Bank 
Muamalat Indonesia Cabang Lampung dalam pelaksanaannya sejalan dengan Prinsip Hukum Islam. Metode penelitian yang digunakan adalah penelitian deskriptif analitis karena untuk memberikan data yang seteliti mungkin tentang manusia, keadaan, atau gejala-gejala lainnya.

\section{B. Pembahasan}

\section{Syarat dan Prosedur Eksekusi Jaminan pada PT Bank Muamalat Indonesia Cabang Lampung}

Praktek eksekusi jaminan tidak terlepas dari bagaimana PT Bank Muamalat Indonesia menyelesaikan permasalahan pembiayaan bermasalahnya. Aturan khusus tentang penyelesaian pembiayaan bermasalah PT Bank Muamalat Indonesia terdapat pada :

a. Buku Pedoman Pembiayaan (BPP) dalam Buku-4: Prosedur Umum Penyelesaian Pembiayaan Bermasalah (PUPBB)

b. Pedoman Penyelesaian Pembiayaan Bermasalah Nomor : REMD.II.071.2014 (P3B)

c. Prosedur Pelaksanaan Penyelesaian Pembiayaan Bermasalah Nomor : REMD.III.152.2014 (P4B)

Syarat untuk melakukan eksekusi jaminan pada PT Bank Muamalat Indonesia Kantor Cabang Lampung adalah melakukan analisa sasaran strategi terhadap kriteria pembiayaan sehingga menghasilkan kesimpulan untuk memutus hubungan dengan nasabah apabila :

a. Prospek usaha tidak optimal dan merugi/tidak menguntungkan sehingga kemampuan membayar sudah tidak ada lagi.

b. Karakter nasabah tidak baik / tidak kooperatif (tidak mau membayar angsuran) / kabur / hilang (tidak diketahui keberadaannya).

c. Kualitas pembiayaan termasuk dalam kategori kolektibilitas III (Kurang Lancar), IV (Diragukan) dan V (macet). Kolektibilitas tersebut ditentukan apabila selama lima bulan berturut-turut (masuk bulan kelima angsuran telah jatuh tempo) nasabah sudah tidak lagi memenuhi pembayaran kewajibannya.

d. Telah dilakukan upaya maksimal terhadap nasabah yaitu berupa pemberitahuan melalui sms (short message service), penagihan melalui telepon, penagihan melalui kunjungan, surat pemberitahuan, surat teguran dan pemberian surat peringatan I, II dan III, secara bertahap hingga bulan ke-tujuh sehingga masuk dalam kolektibilitas Diragukan.

e. Upaya revitalisasi melalui empat cara yaitu : Rescheduling (penjadwalan ulang), Restructuring (penataan ulang), Reconditioning (persyaratan ulang) dan bantuan managemen. Dilakukan melalui usulan dan persetujuan Restrukturisasi serta Realisasi Restrukturisasi dilakukan apabila nasabah dapat kooperatif dan memiliki kemampuan membayar. Namun bila proses Restrukrisasi tidak berhasil maka pelimpahan 
wewenang dari AM Financing diberikan kepada AM Remmedial dengan Penyelesaian melalui Eksekusi/Likuidasi Jaminan, baik secara non litigasi maupun litigasi. ${ }^{1}$

Tabel Prosedur Eksekusi PT Bank Muamalat Indonesia ${ }^{2}$

P4b - Bab II Point 2,5

\begin{tabular}{|c|l|l|}
\hline \multicolumn{2}{|c|}{ PROSEDUR PELAKSANAAN PENYELESAIAN PEMBIAYAAN BERMASALAH } \\
\hline BABII & Tanggal Berlaku::Juni 2014 \\
\hline PERSIAPAN PENYELESAIAN PEMBIAYAAN BERMASALAH & tatus Dokumen & :Revisi 2013 \\
\cline { 2 - 3 } & Bab/Halaman & $: 1 / 7$ \\
\hline
\end{tabular}

2.5.3 Segmentasi Micro And Small Medium Enterprise

\begin{tabular}{|c|c|c|c|c|c|c|c|c|c|c|c|c|c|c|}
\hline \multirow{2}{*}{\multicolumn{2}{|c|}{ Bulan ke- }} & \multirow{3}{*}{$\begin{array}{l}\mathrm{L} \\
\mathrm{x} \\
\mathrm{x}\end{array}$} & \multicolumn{3}{|c|}{ DPK } & \multicolumn{3}{|c|}{$\mathrm{KL}$} & \multicolumn{3}{|c|}{ D } & \multicolumn{3}{|c|}{ M } \\
\hline & & & 1 & 2 & 3 & 4 & 5 & 6 & 7 & 8 & 9 & 10 & 11 & 12 \\
\hline SMS & & & $\mathbf{x}$ & $\mathbf{x}$ & $\mathbf{x}$ & & & & & & & & & \\
\hline Penagihan melalui telepon & & & $x$ & $\mathbf{x}$ & $\mathbf{x}$ & & & & & & & & & \\
\hline Penagihan melalui kunjungan & & & $\mathbf{x}$ & $\mathbf{x}$ & $x$ & $\mathbf{x}$ & $\mathbf{x}$ & $\mathbf{x}$ & $\mathbf{x}$ & & & & & \\
\hline Surat Pemberitahuan & & & $\mathbf{x}$ & & & & & & & & & & & \\
\hline Surat Teguran & & & & $\mathbf{x}$ & & & & & & & & & & \\
\hline Surat Peringatan I & & & & & $\mathbf{x}$ & & & & & & & & & \\
\hline Surat Peringatan II & & & & & $x$ & & & & & & & & & \\
\hline Surat Peringatan III & & & & & & $\mathbf{x}$ & & & & & & & & \\
\hline Usulan dan Persetujuan Restrukturisasi & & $\mathbf{x}$ & $\mathbf{x}$ & $\mathbf{x}$ & $\mathbf{x}$ & $\mathbf{x}$ & $\mathbf{x}$ & $\mathbf{x}$ & $x$ & $\mathbf{x}$ & $\mathbf{x}$ & & & \\
\hline Realisasi Restrukturisasi & & $\mathbf{x}$ & $\mathbf{x}$ & $\mathbf{x}$ & $x$ & $\mathbf{x}$ & $x$ & $\mathbf{x}$ & $x$ & $\mathbf{x}$ & $\mathbf{x}$ & & & \\
\hline $\begin{array}{l}\text { Surat Permintaan Penyelesaian melalui } \\
\text { jaminan secara sukarela dengan } \\
\text { opsi: SKJ atau Offsetting }\end{array}$ & & & & & & & $\mathbf{x}$ & $\mathbf{x}$ & $\mathbf{x}$ & & & & & \\
\hline Surat Kuasa Memasarkan (SKM) & & & & & & & $\mathbf{x}$ & $\mathbf{x}$ & $x$ & & & & & \\
\hline Jual Jaminan dengan SKM & & & & & & & $\mathbf{x}$ & $\mathbf{x}$ & $\mathbf{x}$ & $\mathbf{x}$ & $x$ & $\mathbf{x}$ & $x$ & $x$ \\
\hline Kesediaan Offsetting & & & & & & & $\mathbf{x}$ & $\mathbf{x}$ & $x$ & & & & & \\
\hline Persiapan Offsetting dan Pengosongan & & & & & & & & $\mathbf{x}$ & $x$ & & & & & \\
\hline Usulan dan Persetujuan Offset & & & & & & & & $\mathbf{x}$ & $x$ & & & & & \\
\hline Realisasi Offset & & & & & & & & & $x$ & & & & & \\
\hline Jual AYDA & & & & & & & & & $x$ & & & & & \\
\hline $\begin{array}{l}\text { Surat Pemberitahuan penyelesaian } \\
\text { melalui jaminan secara litigasi }\end{array}$ & & & & & & & & $\mathbf{x}$ & $x$ & $\mathbf{x}$ & $\mathbf{x}$ & $\mathbf{x}$ & $\mathbf{x}$ & \\
\hline Usulan dan Persetujuan Litigasi & & & & & & & & $\mathbf{x}$ & $x$ & $x$ & $x$ & $x$ & $x$ & \\
\hline
\end{tabular}

${ }^{1}$ Prosedur Pelaksanaan Penyelesaian Pembiayaan Bermasalah (P4B) PT Bank Muamalat Indonesia Tbk, Nomor: REMD.III.152.2014, Juni 2014, Persiapan Penyelesaian Pembiayaan Bermasalah, BAB II, p. 7

${ }^{2}$ Ibid. 


\begin{tabular}{|l|l|l|l|l|l|l|l|l|l|l|l|l|l|l|l|l|}
\hline Litigasi - PN + KPKNL & & & & & & & & & & & $\mathbf{x}$ & $\mathbf{x}$ & $\mathbf{x}$ & $\mathbf{x}$ & $\mathbf{x}$ & $\mathbf{x}$ \\
\hline Litigasi - KPKNL & & & & & & & & & & & $\mathbf{x}$ & $\mathbf{x}$ & $\mathbf{x}$ & $\mathbf{x}$ & $\mathbf{x}$ & $\mathbf{x}$ \\
\hline Keterangan: \\
- Untuk penjualan jaminan tidak tertutup kemungkinan pada kolektabilitas lancar \\
\hline - Khusus pembiayaan Mikro, mengikuti tabel tahapan collection pada Prosedur Produk Mikro \\
\hline - Kolektibilitas : L (Lancar), DPK (Dibawah Pengawasan Khusus), K (Kurang Lancar), D (Diragukan), M (Macet) \\
\hline - Merah : Prosedur Eksekusi Jaminan Non Litigasi - Biru : Prosedur Eksekusi Jaminan dengan Litigasi \\
\hline
\end{tabular}

Tabel diatas mengambil contoh Prosedur eksekusi jaminan mengacu pada buku pedoman Prosedur Pelaksanaan Penyelesaian Pembiayaan Bermasalah (P4B) PT Bank Muamalat Indonesia pada Pembiayaan Segmentasi Micro and Small Medium Enterprise. Prosedur Pelaksanaan Eksekusi Jaminan pada Bank Muamalat sebagai berikut: ${ }^{3}$

a. Adapun langkah-langkah yang dilakukan oleh PT Bank Muamalat untuk memulai Eksekusi jaminan sesuai dengan prosedurnya dilakukan pada bulan kelima, apabila nasabah belum juga melaksanakan kewajibannya dan pembiayaannya telah digolongkan dalam kolektibilitas Kurang Lancar, adapun langkah-langkahnya adalah sebagai berikut :

1) Membuat Surat Permintaan Penyelesaian melalui jaminan secara sukarela dengan Opsi SKJ (Surat Kuasa Jual) atau Offsetting.

2) Surat Kuasa Memasarkan (SKM)

3) Jual Jaminan dengan SKM

4) Kesedian Offsetting

5) Persiapan Offsetting dan Pengosongan

6) Usulan dan Persetujuan Offset

7) Realisasi Offset

8) Penjualan AYDA (Agunan Yang Diambil Alih)

Langkah di atas merupakan upaya Eksekusi melalui Jaminan yang dilakukan oleh Bank Muamalat sebagai tahap Non Litigasi hal ini sesuai dengan Pasal 20 ayat (2) dan (3) UUHT Tahun 1996 yaitu eksekusi di bawah tangan, maksudnya adalah penjualan objek Hak Tanggungan berdasarkan kesepakatan dengan pemegang Hak Tanggungan, dengan cara ini diharapkan akan memperoleh harga tinggi.

b. Penyelesaian dengan cara ligitasi adalah penyelesaian pembiayaan melalui jalur hukum yang dilakukan melalui pengadilan.

1) Surat Pemberitahuan Penyelesaian secara litigasi kepada Kepala Cabang.

2) Mengajukan usulan dan meminta persetujuan Litigasi pada Komite Cabang.

${ }^{3}$ Ibid. 
3) Proses Litigasi melalui Pengadilan Agama (PA) dan Kantor Pelayanan Kekayaan Negara dan Lelang (KPKNL).

Dalam tabel masih tertera PN (Pengadilan Negeri), namun saat ini Bank Muamalat hanya boleh menggunakan Pengadilan Agama sebagai tempat beracara dalam menyelesaikan sengketa perbankan dikarenakan Bank Muamalat merujuk pada ketentuan Keputusan Mahkamah Konstitusi No.93/PUU-X/2012 tanggal 29 Agustus 201.

4) Proses Litigasi melalui KPKNL. ${ }^{4}$

Kantor Pelayanan Kekayaan Negara dan Lelang, yang selanjutnya disingkat KPKNL, adalah instansi vertikal Direktorat Jenderal Kekayaan Negara yang berada di bawah dan bertanggung jawab langsung kepada Kepala Kantor Wilayah. Pada hampir seluruh kasus eksekusi jaminan Hak Tanggungan pihak Bank Muamalat langsung melakukan eksekusi pada KPKNL untuk menghemat waktu, biaya dan hasil yang diperoleh agar dapat efektif tanpa melalui proses yang tidak terlalu panjang. Dipilihnya KPKNL langsung tanpa melalui Pengadilan Agama (PA) dilakukan oleh Bank Muamalat dengan syarat apabila :

a) Tidak ada perlawanan hukum dari kreditur

b) Aset lelang dikuasai oleh debitur dan atau pihak ketiga

c) Pihak lain yang ingin membeli AYDA dari Bank Muamalat meminta kepastian hukum yang ditetapkan oleh Pengadilan Agama terhadap Hak Tanggungan yang akan dimilikinya.

Dari data yang telah diperoleh penulis menganalisa bahwa dasar pelaksanaan eksekusi jaminan (Sertifikat Hak Tanggungan) adalah akibat tidak dipenuhinya kewajiban nasabah (wanprestasi) atas fasilitas yang diterimanya dari bank berdasarkan perjanjian pembiayaan. Atas kondisi wanprestasi tersebut, nasabah sudah diberitahu, ditegur dan atau diperingatkan. Namun secara itikad (willingness) maupun kemampuan bayar (capacity) tidak mungkin lagi membayarkan kewajiban, disamping itu nasabah/pemilik jaminan juga tidak kooperatif untuk melakukan penyerahan jaminan secara sukarela dengan mekanisme offsetting.

Ketentuan tentang jenis eksekusi obyek hak tanggungan secara menyeluruh diatur dalam Pasal 20 UUHT Tahun 1996, yaitu :

a. Eksekusi Langsung (parate eksekusi) - vide pasal 6 UUHT jo Pasal 20 ayat (1) UUHT. BMI mempunyai hak untuk menjual obyek hak tanggungan dengan kekuasaan sendiri melalui pelelangan umum serta mengambil pelunasan piutangnya dari hasil penjualan tersebut. Dilakukan dengan bekerjasama pada Balai Lelang Swasta dalam hal ini KPKNL untuk melaksanakan proses lelang.

\footnotetext{
${ }^{4}$ Altop (Wawancara). Account Manager (AM) Remmedial PT Bank Muamalat Indonesia Cabang Lampung. Tanggal 30 Mei 2016.
} 
b. Eksekusi dengan Penetapan Pengadilan (fiat eksekusi) - vide Pasal 14 ayat (2) jo Pasal 20 ayat (2) UUHT. BMI dapat mengajukan eksekusi (fiat eksekusi) melalui Pengadilan Agama merujuk pada ketentuan dalam Pasal 14 Peraturan Menteri Keuangan Republik Indonesia Nomor 27/PMK.06/2016 tentang Petunjuk Pelaksanaan Lelang.

c. Eksekusi dengan penjualan di bawah tangan - vide Pasal 20 ayat (2) dan ayat (3) UUHT. Yang dimaksud penjualan di bawah tangan (Offsetting) adalah penjualan atas tanah yang dijadikan jaminan dan dibebani Hak Tanggungan oleh kreditur sendiri secara langsung kepada orang lain/pihak lain yang berminat, tetapi juga dibantu oleh pemilik tanah dan bangunan dimaksud.

\section{Praktik Pelaksanaan Lelang Eksekusi Jaminan Hak Tanggungan yang Dilakukan oleh PT Bank Muamalat Indonesia Cabang Lampung}

Setelah diberlakukannya Undang Undang No. 4 Tahun 1996 tentang Hak Tanggungan, maka peraturan yang mengatur tentang pembebanan hak atas tanah adalah Bab 21 Buku II KUHPerdata, yang berkaitan dengan hipotik dan Credietverband dalam Staatsblad 1908-542 sebagaimana telah diubah dengan Staatsblad 1937-190 sudah tidak berlaku lagi. Secara formal pembebanan hak atas tanah berlaku ketentuan-ketentuan yang terdapat dalam UUPA, tetapi secara materiil berlaku ketentuan yang tercantum dalam Bab 21 Buku II KUHPerdata dan Credietverband.

Menurut Pasal 1234 KUHPerdata ada tiga macam prestasi yang dapat diperjanjikan untuk tiap perikatan, yaitu untuk memberikan sesuatu, berbuat sesuatu, dan untuk tidak berbuat sesuatu. Sedangkan wanprestasi adalah suatu keadaan dimana seseorang tidak memenuhi kewajiban yang didasarkan pada suatu kontrak atau perjanjian. Berdasarkan hasil penelitian dalam pelaksanaan eksekusi Hak Tanggungan yang dipraktikkan oleh PT Bank Muamalat Indonesia Cabang Lampung, berikut : 


\section{Bagan Alur Eksekusi Jaminan Hak Tanggungan}

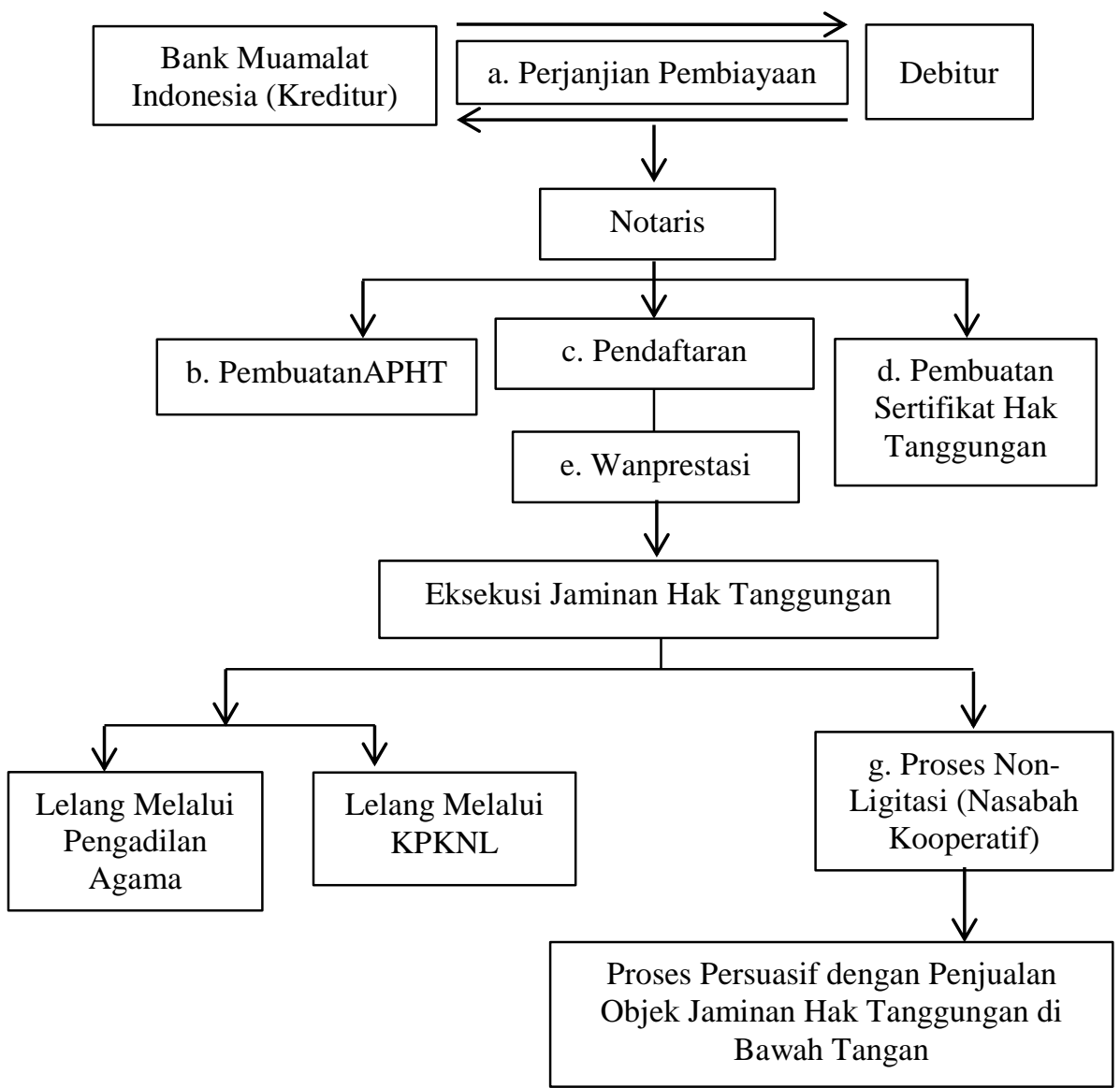

Keterangan Bagan Eksekusi Jaminan Hak Tanggungan diatas adalah :

a. Tahap pertama yaitu pengikatan perjanjian pembiayaan antara nasabah dengan PT Bank Muamalat Indonesia.

b. Tahap kedua yaitu pembuatan Akta Pemberian Hak Tanggungan (APHT) yang dibuat oleh Petugas Pembuat Akta Tanah (PPAT).

c. Tahap ketiga yaitu pendaftaran Hak Tanggungan

d. Tahap keempat yaitu tentang pembuatan sertipikat Hak Tanggungan.

e. Tahap kelima yaitu apabila nasabah terbukti melakukan wanprestasi kepada Bank dengan sudah diupayakan penyelamatan terhadap perjanjian pembiayaan oleh bank, maka bank selaku pemegang sertipikat jaminan Hak Tanggungan dapat melakukan eksekusi pada sertipikat Hak Tanggungan.

f. Proses Non Litigasi, nasabah bersikap kooperatif. 
g. Proses Litigasi, apabila nasabah tidak bersikap kooperatif.

Pertama, melalui Pengadilan Agama, PT Bank Muamalat Indonesia meminta fiat eksekusi kepada Pengadilan untuk memproses dan mengurusinya dari pra lelang sampai proses lelang. Prosedur Penyelesaian Eksekusi Hak Tanggungan di Pengadilan Agama :

a. Pemohon mengajukan permohonan eksekusi Hak Tanggungan kepada Ketua Pengadilan Agama dengan melampirkan :

1) Fotocopy Sertifikat Hak Tanggungan yang memuat irah-irah "Demi Keadilan Berdasarkan Ketuhanan Yang Maha Esa".

2) Fotocopy Surat Perjanjian (Akad Syariah) utang piutang antara Pihak Kreditur dengan Debitur.

3) Fotocopy Bukti Pendaftaran Hak Tanggungan pada Kantor Pertanahan.

4) Fotocopy surart-surat teguran/peringatan dari Bank kepada Debitur atas kelalaiannya membayar cicilan utang.

5) Surat Kuasa yang masih berlaku, jika Pemohon eksekusi menggunakan kuasa hukum.

b. Aanmaning (Melaksanakan Peringatan)

Setelah menerima permohonan eksekusi Hak Tanggungan dari Pemohon (Bank), Ketua Pengadilan Agama, memerintahkan Juru Sita/ Juru Sita Pengganti untuk memanggil Debitur yang ingkar janji untuk ditegur (aanmaning), dan teguran ini sebaiknya dilakukan sebanyak 2 kali dan dalam waktu 8 hari harus memenuhi kewajibannya, yaitu membayar utangnya dengan sukarela.

Dalam aanmaning ini apabila nasabah bersedia memenuhi kewajibannya kepada bank melalui bayar tunai ataupun jual jaminan secara sukarela dimana hasil dari penjualan tersebut digunakan untuk melunasi kewajiban (pelaksanaan Pasal 6 Undang-Undang Hak Tanggungan), maka permohonan eksekusi dapat dicabut oleh pihak bank. Adapun bila nasabah tidak bersedia memenuhi kewajiban, maka akan dilakukan tahap selanjutnya yaitu Sita Eksekusi.

\section{c. Sita Eksekusi}

Jika pihak Debitur tidak dapat memenuhi kewajibannya dengan sukarela, kemudian Ketua Pengadilan Agama memerintahkan agar tanah objek Hak Tanggungan tersebut disita dengan sita eksekutorial oleh Panitera atau Penggantinya dengan dibantu 2 orang saksi yang memenuhi persyaratan untuk melaksanakan eksekusi sesuai dengan amar putusan dan pelaksanaan eksekusi dituangkan dalam berita acara eksekusi (Pasal 29 ayat (4) R.Bg).

Panitera atau Penggantinya yang telah melakukan penyitaan tersebut membuat Berita Acara Tentang Penyitaan itu dan memberitahukan maksudnya kepada orang yang barangnya tersita apabila ia hadir pada waktu 
itu. Apabila yang disita berupa barang tidak bergerak (tanah) yang sudah didaftarkan pada kantor pendaftaran tanah, maka berita acara penyitaan itu diberitahukan kepada Kepala Kantor Pendaftaran Tanah yang bersangkutan. Akan tetapi jika tanah yang disita itu belum didaftarkan, maka berita acara penyitaan diumumkan oleh Panitera/Penggantinya. Kemudian meminta kepada Kepala Desa/Lurah setempat mengumumkan seluas-luasnya di tempat itu dengan cara yang lazim digunakan didaerah itu. Jangka waktu Sita Eksekusi adalah 8 (delapan) hari. Bila dalam jangka waktu ini nasabah tidak bersedia memenuhi kewajibannya, maka proses selanjutnya adalah pengajuan permohonan lelang.

\section{d. Penjualan Lelang}

Permohonan lelang ditindaklanjuti oleh PA dengan dikeluarkannya Penetapan Lelang yang ditandatangani oleh Ketua PA dan pada masa itu pula PA mengurus SKPT (Surat Keterangan Pendaftaran Tanah) ke BPN (Badan Pertanahan Negara), permintaan NJOP (Nilai Wajib Objek Pajak) kepada Kantor PBB (Pajak Bumi dan Bangunan) dan mengumumkan pelaksanaan lelang di Media Massa sebanyak 2 (dua) kali. Masa Pra lelang ini berlangsung selama kurang lebih 35 hari. Pada tahap ini, nasabah (termohon eksekusi) dapat mengajukan bantahan/keberatan atas lelang yang akan dilaksanakan. Bila ada keberatan, maka lelang ditunda dan dilakukan sidang untuk mengkaji apakah alasan yang diajukan dapat diterima atau ditolak. Jika alasannya dapat diterima maka hakim dapat memutuskan pembatalan lelang. Namun apabila ditolak, proses lelang tetap dilaksanakan.

Pelelangan atas barang tidak bergerak berupa Tanah milik Debitur yang dijadikan jaminan, dilakukan dengan perantaraan bantuan Kantor Pelayanan Kekayaan Negara dan Lelang (KPKNL) didaerah yang bersangkutan.

Hasil penjualan lelang akan dipergunakan untuk membayar tagihan kepada bank/Kreditur, setelah dibayar/dikeluarkan terlebih dahulu biaya lelang dan apabila ada kelebihan, maka uang tersebut akan dikembalikan kepada Penanggung Utang/ Nasabah Debitur.

Kedua, PT Bank Muamalat Indonesia langsung melakukan lelang dengan mendaftarkannya ke Kantor Pelayanan Kekayaan Negara dan Lelang (KPKNL) tanpa melalui proses pengadilan.

Sebelum lelang dilakukan, bank akan meminta nasabah debitur untuk melengkapi dokumen persyaratan lelang Hak Tanggungan berdasarkan Pasal 6 UUHT adalah sebagai berikut :

1) Surat permohonan lelang dari kreditur sebagai penjual.

2) Syarat lelang dari penjual.

3) Asli dan fotocopy bukti kepemilikan atau hak.

4) Asli atau fotocopy surat keputusan penunjukan penjual. 
5) Daftar barang yang akan dilelang.

6) Salinan perjanjian kredit atau pembiayaan.

7) Salinan sertipikat Hak Tanggungan atau Akta Pemberian Hak Tanggungan.

8) Asli atau fotocopy bukti bahwa debitur wanprestasi yang dapat berupa peringatan-peringatan dari kreditur terhadap debitur maupun pernyataan dari pihak kreditur.

9) Surat pernyataan dari kreditur yang akan bertanggung jawab apabila terjadi gugatan.

10) Perincian hutang, denda dan hutang

Kemudian Kepala Kantor Pelayanan Kekayaan Negara dan Lelang (KPKNL) menetapkan hari, dan tanggal pelaksanaan lelang setelah dilakukan analisa kelengkapan dokumen. Pemohon (BMI) melaksanakan pengumuman lelang melalui surat kabar harian atau media elektronik dengan ketentuan pengumuman pertama dan kedua berjarak 15 hari, dan pengumuman kedua, pelaksanaan lelang tidak boleh kurang dari 14 hari.

Pelaksanaan lelang diawali dengan penawaran secara tertulis (tertutup) dari para peserta, kemudian apabila penawaran tertinggi dari peserta telah melampaui limit lelang yang ditetapkan, maka peserta dengan penawaran tertinggi tersebut ditunjuk sebagai pemenang lelang, namun apabila penawaran belum melampaui limit lelang, penawaran dilanjutkan dengan penawaran terbuka secara naik-naik hingga diperoleh harga tertinggi di atas limit lelang. Jika tahap inipun penawaran tertinggi belum melampaui limit lelang, maka lelang akan diulang dalam jangka waktu kurang lebih dalam satu bulan ke depan dan hal ini mempunyai implikasi biaya. (merujuk pada PMK Nomor 27/PMK.06/2016 tentang Petunjuk Pelaksanaan Lelang).

Setelah pemenang ditunjuk, maka dilakukan pembayaran dimana hasil dari penjualan tersebut digunakan untuk penyelesaian pembiayaan yang ada. Setelah itu pemenang lelang akan mendapatkan Risalah Lelang untuk melakukan Balik Nama ke BPN (Badan Pertanahan Negara). Pengosongan terhadap objek lelang dilakukan apabila perlu dengan meminta bantuan Muspida setempat. Proses terakhir adalah Proses Balik Nama diproses BPN.

Walaupun hukum materiil yang mengatur mengenai hukum ekonomi syariah belum ada, berdasarkan UU Nomor 3 Tahun 2006 tentang Peradilan Agama pada Pasal 49 dinyatakan bahwa yang dimaksud dengan "antara orang-orang beragama Islam" adalah termasuk orang atau badan hukum yang dengan sendirinya menundukkan diri dengan sukarela kepada hukum Islam mengenai hal-hal yang menjadi kewenangan peradilan agama. Serta Pasal 50 ayat (2) yang menyebutkan "Apabila terjadi sengketa hak milik yang subjek hukumnya antara orang-orang yang beragama Islam, objek sengketa tersebut diputus oleh pengadilan agama bersama-sama perkara". Maka Pengadilan Agama tidak boleh menolak untuk memeriksa, mengadili 
dan memutus suatu perkara dengan dalih bahwa hukum tidak ada atau kurang jelas, melainkan wajib untuk mengadili dan memeriksanya.

Sebagaimana UU Nomor 3 Tahun 2006, maka Pengadilan Agama diberi kewenangan untuk mengadili sengketa ekonomi syariah, maka Pengadilan Agama mempunyai kewenangan pula dalam melaksanakan eksekusi terhadap barang jaminan yang diagunkan pada bank syariah, karena pada dasarnya perjanjian jaminan adalah perjanjian yang bersifat accesoir terhadap perjanjian pokok. Apabila dalam suatu jenis pembiayaan akad syariah dibarengi dengan perjanjian jaminan, maka perjanjian jaminan tersebut melekat pula prinsip syariah, sehingga jika terjadi sengketa maka Pengadilan Agama berwenang menyelesaikannya. ${ }^{5}$

Namun dilihat dari sertifikat Hak Tanggungan yang berlaku sebagai pengganti grosse acte hypotheek, pelaksanaan eksekusinya memperhatikan pula ketentuan hukum acara perdata yang berlaku.

Ketentuan dalam Pasal 26 UUHT menetapkan, bahwa:

"Selama belum ada peraturan perundang-undangan yang mengaturnya dengan memperhatikan ketentuan dalam Pasal 14, peraturan mengenai eksekusi hipotek yang ada pada mulai berlakunya undang-undang ini, berlaku terhadap eksekusi Hak Tanggungan."

Berdasarkan ketentuan dalam Pasal 26 UUHT beserta dengan penjelasannya berarti, untuk pelaksanaan eksekusi Hak Tanggungan ditunjuk lagi dan dinyatakan berlaku peraturan perundang-undangan yang mengatur mengenai eksekusi hypotheek yang berlaku saat ini, sepanjang UUHT atau peraturan perundang-undangan lainnya belum mengatur secara khusus eksekusi Hak Tanggungan. Dengan kata lain, ketentuan hukum acara perdata yang ada dan ketentuan-ketentuan hipotek sebagaimana tersebut dalam Buku Kedua KUH Perdata berlaku pula terhadap eksekusi Hak Tanggungan, sepanjang peraturan perundang-undangan yang mengatur secara khusus eksekusi Hak Tanggungan belum ada, cukup dengan cara menyerahkan sertifikat Hak Tanggungan sebagai dasar pelaksanaan eksekusi benda yang menjadi objek Hak Tanggungan.

\section{Eksekusi Jaminan Hak Tanggungan yang Dilakukan oleh PT Bank Muamalat Indonesia Cabang Lampung dalam Pelaksanaannya Sejalan dengan Prinsip Hukum Islam}

Secara umum jaminan dalam hukum Islam yang menggunakan akad syariah dibagi menjadi dua: jaminan yang berupa orang (personal

\footnotetext{
${ }^{5}$ Muttaqien, Dadan dan Cikman, Fakhruddin. (2010). Penyelesaian Sengketa Perbankan Syariah. Yogyakarta: Total Media, p.114.
} 
guanrantee) seringkali dikenal dengan istilah kafalah dan jaminan yang berupa harta benda dikenal dengan rahn.

Namun dalam praktek operasional Bank Syariah, jika barang agunan tersebut adalah berupa sebidang tanah pada kontrak pembiayaannya menggunakan Hukum Jaminan Hak Tanggungan. Hal ini disebabkan Pengaturan penggunaan jaminan Hak Atas Tanah dalam pembiayaan pada Bank Syariah belum ada dalam ketentuan syariah. Hingga saat ini, rahn dipergunakan bagi agunan yang disimpan dalam transaksi Gadai sedangkan kafalah hanya mengacu pada Bank Garansi (mengalihkan tanggung jawab seseorang yang dijamin dengan berpegang pada tanggung jawab orang lain sebagai penjamin/bank syariah).

Dari uraian tentang konsep di atas, eksistensi jaminan diakui dalam hukum Islam. Untuk jaminan yang diberikan oleh pihak lain atas kewajiban/prestasi yang harus dilaksanakan oleh pihak yang dijamin (debitur) kepada pihak yang berhak menerima pemenuhan kewajiban/prestasi (debitur) disebut dengan kafalah. Sedangkan jaminan yang terkait dengan benda/harta yang harus diberikan debitur (orang yang berhutang) kepada kreditur (orang yang berpiutang) disebut dengan rahn.

Sebagai perbandingan, dalam sistem yang berlaku di Indonesia jaminan digolongkan mejadi dua macam, yaitu jaminan materiil (kebendaan) dan jaminan immateriil (perorangan, borgtocht). Jaminan kebendaan mempunyai ciri-ciri "kebendaan" dalam arti memberikan hak memdahului di atas benda-benda tertentu dan mempunyai sifat melekat dan mengikuti benda yang bersangkutan. Sedangkan jaminan perorangan tidak memberikan hak mendahului atas benda-benda tertentu, tetapi hanya dijamin oleh harta kekayaan seseorang lewat orang yang menjamin pemenuhan perikatan yang bersangkutan.

Untuk lebih mengkhususkan analisa maka penulis membahas dengan jaminan yang sesuai dengan prinsip hukum Islam terkait dengan benda/harta yang harus diberikan debitur (orang yang berhutang) kepada kreditur (orang yang berpiutang) disebut dengan Rahn dengan membandingkan Hukum Hak Tanggungan mengacu pada Undang Undang Nomor 4 Tahun 1996 Tentang Hak Tanggungan Atas Tanah Beserta Benda-Benda Yang Berkaitan Dengan Tanah hingga persoalan eksekusi yang terdapat dalam Hukum Hak Tanggungan (UUHT) itu sendiri.

a. Dalil Al-Qur'an.

Allah SWT berfirman :

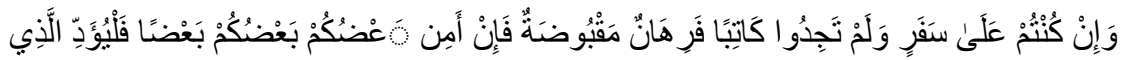

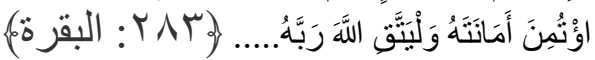


"Jika kamu dalam perjalanan (dan bermuamalah tidak secara tunai), sedang kamu tidak memperoleh seorang penulis, maka hendaklah ada barang tanggungan yang dipegang (oleh yang berpiutang). Akan tetapi, jika sebagian kamu mempercayai sebagian yang lain, maka hendaklah yang dipercayai itu menunaikan amanatnya (utangnya), dan hendaklah ia bertakwa kepada Allah, Tuhannya;..... (Al-Baqarah : 283)

\section{b. Dalil Hadist / Sunnah Rasulullah}

"Dari Aisyah bahwasannya Nabi Muhammad SAW pernah membeli bahan makanan dari seorang Yahudi dengan utang dan beliau memberikan baju besinya sebagai jaminan." (HR Bukhari, Muslim, dan Nasai). ${ }^{6}$

Mengambil agunan untuk jaminan utang, menurut al-Quran dan Sunnah pada dasarnya bukan suatu yang tercela. Nabi dalam beberapa kesempatan mempersilahkan krediturnya untuk mengambil agunan untuk utangnya. Agunan adalah suatu cara untuk menjamin kreditur agar tidak melanggar perjanjian dan menghindari memakan harta orang lain.

Bersumber dari Amir ibn Syuraid dari ayahnya dari Nabi SAW, beliau besabda, "Penundaan orang yang sudah mampu membayar utang itu adalah zalim yang membolehkan untuk melaporkan dan memaksanya.(HR Imam yang lima (Bukhari, Muslim, Abu Daud, An-Nasa'i, Ibnu Majah) kecuali Imam Tirmidzi) ${ }^{7}$

Sedangkan untuk barang yang dijadikan agunan dalam hutang piutang maka Syariat Islam mengaturnya dalam Hadist dari Abu Hurairah r.a. bahwa Rasulullah bersabda, "Siapapun yang bangkrut (muflis), lalu krediturnya mendapatkan barangnya sendiri pada si bangkrut, maka kreditur itu lebih berhak untuk menarik kembali barangnya dari pada lainnya." (Hadist dikeluarkan oleh Bukhari, Muslim, Tirmidzi, Nasa'i dan Ibnu Majah). ${ }^{8}$

\section{c. Dalil Ar-Ro'yah / Ijtihad.}

Secara umum, Fiqh Muamalah telah menyandarkan ketentuan jaminan pada rahn. Dalam etimologi, kata ar-rahn berarti tetap, kekal dan jaminan. ${ }^{9}$

\footnotetext{
${ }^{6}$ Shahih Bukhari Nomor. 1926, 1954, 2049; Shahih Muslim Bab Bolehnya Gadai Nomor. 3007, 3008, 3009; An-Nasa'I Nomor. 4530, 4571.

${ }^{7}$ Shahih Bukhari Bab III Nomor 55; Shahih Muslim 85 Bab III Nomor 1197, 1564; Syarah Imam Abu Daud Nomor 3628; Syarah Imam An-Nasa'I Nomor. 4689; Syarah Imam Ibnu Majah Nomor. 2427.

${ }^{8}$ Shahih Bukhari Nomor 2404 disarikan oleh Fathul Bari'; Shahih Muslim Nomor 1559 disarikan oleh Al-Hafizh Ibnu Hajar Al-Asqalani.

${ }^{9}$ Ad-Dardir, 1978, Syarh al Shagir ash Shawi, (Mesir : Dar al-Fikr), Jilid III, p. 303.
} 
Akad ar-rahn dalam istilah hukum positif disebut dengan barang jaminan, menurut para ulama dalam 4 mazhab menyebutkan:

a. Ulama Malikiyyah mendefinisikan rahn sebagai harta yang dijadikan pemiliknya untuk jaminan pembayaran hutang yang sifatnya mengikat. Obyek jaminan dapat berbentuk materi, atau manfaat, dimana keduanya merupakan harta menurut jumhur ulama. Barang yang dijadikan barang jaminan tidak harus diserahkan secara aktual tetapi boleh juga penyerahannya secara hukum, seperti menjadikan sawah sebagai jaminan, sehingga yang diserahkan adalah surat jaminannya (sertifikat sawah). ${ }^{10}$

b. Ulama Hanafiyyah Rahn adalah suatu barang yang dijadikan sebagai jaminan terhadap piutang baik yang sebagian maupun seluruhnya. ${ }^{11}$

c. Ulama Syafii dan Hambali bahwa rahn dijadikan barang sebagai jaminan pembayaran hutang apabila pihak yang berhutang tidak mampu melunasi. Definisi ini mengandung pengertian bahwa barang yang boleh dijadikan jaminan utang itu hanya yang bersifat materi, tidak termasuk manfaat sebagaimana yang dikemukakan ulama mazhab Maliki. Barang jaminan itu boleh dijual apabila utang tidak dapat dilunasi dalam waktu yang disepakati kedua belah pihak. ${ }^{12}$

Di samping itu syarat-syarat di atas, para ulama fiqh sepakat menyatakan bahwa ar-rahn itu baru dianggap sempurna apabila barang yang di rahn-kan itu secara hukum sudah berada di tangan pemberi utang, dan uang yang dibutuhkan telah diterima peminjam uang. Apabila barang jaminan itu berupa benda tidak bergerak, seperti rumah dan tanah, cukup surat jaminan tanah atau surat-surat rumah itu yang dipegang oleh pemberi utang. Syarat yang terakhir (kesempurnaan ar-rahn) oleh para ulama disebut sebagai qabdh al-marhun (barang jaminan dikuasai secara hukum). Syarat ini menjadi penting karena Allah dalam surah al-Baqarah ayat 283 menyatakan: "fa rihaanun maqbuudhatun" (barang jaminan itu dikuasai (secara hukum).

Adapun keabsahan mengenai penggunaan UUHT dalam eksekusi jaminan pada PT Bank Muamalat Indonesia pembahasannya dilakukan dengan ilmu Ushul Fiqh yang ada. Adapun pengertian dari Ushul Fiqh adalah Kumpulan dari qaidah-qaidah dan pembahasan-pembahasan dalildalil syari'at dari segi penunjukannya kepada hukum-hukum serta tentang hukum-hukum dari segi pengambilannya dari dalil-dalil syari'at, dan hal-hal

\footnotetext{
${ }^{10}$ Ibid, p. 325.

${ }^{11}$ Sjahdeni, Sutan Remy. (2005). Perbankan Islam dan Kedudukannya dalam Tata Hukum Perbankan Indonesia. Jakarta: PT Kreatama, p. 75.

12 Abidin, Ibnu. (1963). Radd al-Mukhtar 'ala ad-Durr al-Mukhtar Jilid V. Beirut: Dar alFikr, p. 339.
} 
yang erat hubungannya dengan qaidah-qaidah dan pembahasan-pembahasan itu yang membentuk suatu ilmu. ${ }^{13}$.

Kaidah Ushul Fiqh yang digunakan adalah:

a. Qaidah "Al-Ashalu fil asyaa'al ibaaha hatta yudhillu daliilan 'ala tahriimihaa" (Dasar pada setiap sesuatu pekerjaan adalah boleh sampai ada dalil yang mengaharamkannya).

b. Qaidah "Al- 'umuuru bimaqaasidihaa" (Segala urusan tergantung kepada tujuannya). Dari qaidah ini dibahas sesuai dengan teori Mashalihul Mursalah yaitu suatu kemaslahatan yang tidak ditetapkan oleh syara' suatu hukum untuk mewujudkannya dan tidak pula terdapat suatu dalil syara' yang memerintahkan untuk memperhatikannya atau mengabaikannya.

c. Qaidah "Al-'adatu muhakkamah" (Adat kebiasaan itu merupakan syari'at yang ditetapkan sebagai hukum). Dari qaidah ini dibahas sesuai dengan Urf atau adat kebiasaan adalah apa-apa yang telah dibiasakan oleh masyarakat dan dijalankan terus menerus baik berupa perkataan maupun perbuatan. ${ }^{14}$

Dari uraian diatas jaminan hak tanggungan yang selalu dipakai di perbankan syariah walaupun tidak menyalahi aturan Islam, tetap harus ada pengaturan dalam hukum Islam yang bisa dikatakan "Hak Tanggungan Syariah", sehingga kebiasaan yang sudah terjadi dalam masyarakat dan perbankan syariah yang menggunakan hak tanggungan bisa ditinggalkan dan menggunakan jaminan syariah karena sesuai dengan akadnya yaitu syariah. Maka perlu pengaturan hukum mengenai jaminan yang sesuai atau berlandaskan hukum Islam. Hukum Islam pun harus punya aturan hukum mengenai jaminan. Salah satunya rahn, sehingga penulis beranggapan bahwa belum ada produk hukum resmi yang dikeluarkan oleh pemerintah atas stakeholder (pembuat kebijakan) untuk mengeluarkan tata aturan penggunaan Ar-Rahn sebagai lembaga jaminan transaksi syariah yang mengakomodir segala kontrak atau akad menggunakan fasilitas pembiayaan syariah, serta tata cara penanganan resiko yang meliputinya. Salah satunya pengaturan eksekusi terhadap jaminan apabila pihak yang berhutang mengingkari perjanjian.

\section{Penutup}

\section{Simpulan}

Syarat untuk melakukan eksekusi jaminan pada PT Bank Muamalat Cabang Lampung telah sesuai dengan ketentuan yang berlaku. Sedangkan

\footnotetext{
13 Yahya, Mukhtar dan Rahman, Fatchur. (1999). Dasar Dasar Pembinaan Hukum Fiqh Islam. Bandung: PT. Al-Ma'arif, p.17.

${ }^{14}$ Ibid, p. 109.
} 
prosedur eksekusi jaminan pada PT Bank Muamalat Cabang Lampung berupa:

a. Eksekusi jaminan melalui tahapan Non Litigasi Sesuai Pasal 20 ayat (2) dan (3) dengan UUHT Tahun 1996 yaitu eksekusi di bawah tangan, maksudnya adalah penjualan objek Hak Tanggungan berdasarkan kesepakatan dengan pemegang Hak Tanggungan (Offseting).

b. Penyelesaian melalui tahapan ligitasi adalah penyelesaian pembiayaan melalui jalur hukum yang dilakukan melalui pengadilan. Eksekusi melalui jalur Litigasi ini dilakukan PT Bank Muamalat Indonesia melalui Pengadilan Agama (PA) atau Kantor Pelayanan Kekayaan Negara dan Lelang (KPKNL)

Praktik pelaksanaan lelang eksekusi jaminan hak tanggungan yang dilakukan oleh PT Bank Muamalat Indonesia Kantor Cabang Lampung melalui jalur Litigasi meliputi eksekusi pada :

a. Pengadilan Agama, PT Bank Muamalat Indonesia meminta fiat eksekusi kepada Pengadilan untuk memproses dan mengurusinya dari pra lelang sampai proses lelang sesuai dengan Pasal 14 ayat (2) UUHT. Dipilihnya Pengadilan Agama (PA) dalam eksekusi jaminan apabila ada perlawanan hukum dari kreditur, aset lelang dikuasai oleh debitur dan atau pihak ketiga dan kepastian hukum.

b. Bank dapat memilih melakukan lelang dengan mendaftarkannya ke Kantor Pelayanan Kekayaan Negara dan Lelang (KPKNL) tanpa melalui proses pengadilan. Sesuai dengan Pasal 6 UUHT. Dipilihnya KPKNL oleh Bank dikarenakan biaya terjangkau, jangka waktu relatif lebih singkat.

Eksekusi jaminan hak tanggungan yang dilakukan PT Bank Muamalat Cabang Lampung masih menggunakan Undang-Undang Nomor 4 Tahun 1996 tentang Hak Tanggungan dilihat sudah sesuai dengan kaidah Mashahilul Mursalah (Kemaslahatan Bersama) dan Al- 'Urf (Kebiasaan dan Adat - Istiadat) yang telah berlaku Indonesia untuk mengatur keadilan dan ketertiban di masyarakatnya.

\section{Saran}

a. Pengikatan pembiayaan yang dilakukan oleh Bank Syariah sebaiknya jangan sampai terjadi cacat hukum, baik mengenai perjanjian pokoknya (akad pembiayaan) maupun perjanjian tambahannya.

b. Bank Syariah dalam memberikan pembiayaan kepada nasabah agar lebih berhati-hati serta mengoptimalkan penyelesaian pembiayaan menggunakan dasar hukum Undang-Undang Hak Tanggungan. 


\section{Daftar Pustaka}

\section{A. Buku dan Jurnal}

Abidin, Ibnu (1963). Radd al-Mukhtar 'ala ad-Durr al-Mukhtar. Beirut: Dar al-Fikr.

Ad-Dardir. (1978). Syarh al Shagir ash Shawi. Jilid III. Mesir: Dar al-Fikr.

Muttaqien, Dadan, dan Cikman, Fakhruddin. (2010). Penyelesaian Sengketa Perbankan Syariah. Yogyakarta: Total Media.

Moleong, Lexy J., (1995). Metodologi Penelitian Kualitatif. Bandung: PT Remaja. Rosdakarya.

Musjtari, Dewi Nurul. (2012). Penyelesaian Sengketa dalam Praktik Perbakan Syariah. Yogyakarta: Parama Publishing.

Sjahdeni, Sutan Remy. (2005). Perbankan Islam dan Kedudukannya dalam Tata Hukum Perbankan Indonesia. Jakarta: PT Kreatama.

Soekanto, Soerjono. (1986). Pengantar Penelitian Hukum. Jakarta: UI Press. Yahya, Mukhtar, dan Rahman, Fatchur. (1999). Dasar Dasar Pembinaan Hukum Fiqh Islam. Bandung: PT. Al-Ma'arif.

\section{B. Sumber Lain}

Kitab Undang-Undang Hukum Perdata (Burgerlijk Wetboek). (2009). Diterjemahkan oleh R. Subekti dan R.Tjitrosudibio. Jakarta: Pradnya Paramita.

Undang-Undang Nomor 4 Tahun 1996 tentang Hak Tanggungan (Lembaran Negara Republik Indonesia Tahun 1996 Nomor 42, tambahan Lembaran Negara Nomor 3632)

Undang-Undang Nomor 3 Tahun 2006 tentang Perubahan Atas UndangUndang Nomor 7 Tahun 1989 tentang Peradilan Agama (Lembaran

Negara Republik Indonesia Tahun 2006 Nomor 22 dan tambahan Lembaran Negara Republik Indonesia Nomor 4611)

Keputusan Menteri Keuangan RI No.27/PMK.06/2016 tentang Petunjuk Pelaksanaan Lelang

Prosedur Pelaksanaan Penyelesaian Pembiayaan Bermasalah (P4B) PT Bank

Muamalat Indonesia Tbk, Nomor: REMD.III.152.2014, Juni 2014,

Persiapan Penyelesaian Pembiayaan Bermasalah, BAB II

Shahih Hadist Imam Bukhari dan Muslim

Syarah Hadist Imam Abu Daud, Imam An-Nasa'I dan Imam Ibnu Majah 
